\title{
INDUSTRY CONSOLIDATION AND FUTURE AIRLINE NETWORK STRUCTURES IN EUROPE
}

\author{
Dr Nigel Dennis \\ Senior Research Fellow \\ Transport Studies Group \\ University of Westminster \\ 35 Marylebone Road \\ LONDON NW1 5LS \\ Tel: +442079115000 ext 3344 \\ Fax: +442079115057 \\ e-mail: dennisn@westminster.ac.uk
}

\begin{abstract}
In the current downturn in demand for air travel, major airlines are revising and rationalising their networks in an attempt to improve financial performance and strengthen their defences against both new entrants and traditional rivals. Expansion of commercial agreements or alliances with other airlines has become a key reaction to the increasingly competitive marketplace. In the absence, for reguiatory reasons, of cross-border mergers these are the principal means by which the industry can consolidate internationally. The failure of airlines such as Sabena and Swissair has also enforced restructuring at some of Europe's busier airports. This paper analyses the developments which have been taking place and attempts to identify the implications for airline network structures and the function of different hub airports.
\end{abstract}

Airlines have rationalised their networks by withdrawing services that feed the hubs of rival alliances. New links have however been created that are made feasihle by the alliance support. The range of services available to passengers in long haul markets to/from Europe is evaluated before and after recent industry reorganisation.

Hubs are crucial to interlink the route networks of partners in an alliance. However, duplication between nearby hub airports that find themselves within the same airline alliance can lead to loss of service at the weaker locations. The extent to which the alliance hubs in Europe duplicate or complement each other in terms of network coverage is assessed and this methodology also enables the optimal partnerships for 'unattached' airlines to be identified. The future role of the various European hubs is considered under different scenarios of global alliance development.

The paper concludes by considering possible longer-term developments. In an environment where the low-cost carriers will provide a major element of customer choice, it is suggested that the traditional airlines will retrench around their hubs, surrendering many secondary cities to the low-cost sector. Further reduction in the number of alliances could threaten more of the European hubs. For both regulatory and commercial reasons, the end result may be just one airline alliance - so recreating in the deregulated market the historic role of IATA.

Keywords

airline, airport, network, hub, alliance, competition 


\section{Introduction}

The downturn in demand for air travel that followed the terrorist attacks of September 11th 2001, magnified by the weak economic conditions in many major countries and more recently the looming war against Iraq and the SARS epidemic have made the last two years unhappy ones for most of the world's airlines.

For almost the first time, demand for air travel cannot be assumed to follow an ever ris ing trend. Airlines have reacted by cutting back the weaker parts of their network and operations and aiming for more co-operation and consolidation within the industry to curb excess capacity. Many of these changes were overdue and it is difficult to attribute them directly to the downturn following September 11 th. It has however created a business environment where more radical measures can be implemented.

The major airlines have moved to strengthen their position in the marketplace by consolidating operations under one brand. In some cases this involved the merger or take-over of an independent rival (for example, SAS acquired its Norwegian rival Braathens and American Airlines has takenover the ailing TWA). Franchising, whereby one airline licences its product and identity to another is an alternative method for the major carriers to extend their brand presence while leaving the commercial risk with the franchisee (Denton \& Dennis, 2000). Other secondary forms of collaboration include joint operations and code-sharing agreements which may be organised on an ad-hoc route by route basis.

One of the most important developments in the global arena is the emergence of international airline alliances (Hanlon, 1999). Examples are the Star Alliance, which includes Lufthansa and United amongst others or SkyTeam which is based around Air France and Delta. These aim to extend the reach of an individual airline network by linking it with services of partner carriers. This increases the number of city pairs that can be served compared to the airlines operating individually, enables joint scheduling and marketing, combination of frequent flier programmes, combined purchasing and sharing of services and infrastructure. In a downturn of demand, alliances also enable consolidation of capacity, at both the route and network level.

Alliances, mergers, franchising and code sharing arrangements all have the effect of reducing the number of carriers operating at an airport which has the potential to diminish competition and increases the risk to airport operators and communities should the dominant operator change strategy or go out of business. This paper aims to investigate the impact of this re-shaping of the airline industry on airline networks in Europe. Specific attention is given to the likely winners and losers among airports from current airline commercial developments and future strategies are discussed.

\section{Changes in long-haul coverage}

The greatest downturn in demand since September 2001 has come in intercontinental markets such as the North Atlantic and Europe-Middle East. This has accelerated the rationalisation by many airlines of their long-haul services. In Europe, too many small countries have attempted to maintain a national 'flag carrier' with an intercontinental presence. The larger airlines often had several 
airports in their home country from which they flew long-haul. It is generally less efficient to split long haul services between hubs and airlines had already started addressing this problem prior to September 11th, with Swissair moving long-haul routes from Geneva to Zurich and BA deciding to concentrate on Heathrow at the expense of Gatwick (Halstead, 2001).

Tables 1 and 2 consider the change in long-haul service at European airports from Summer 2000 (generally acknowledged to be the high-point of the aviation industry) to Summer 2003. Table 1 takes only the cities with a daily service by the major hub airline (including code-shares). This is a good yardstick of the principal route network, being the minimum frequency necessary in most markets to compete with the strongest airlines (including those with hubs outside Europe). Multistop services are included as long as there is no aircraft change involved.

It can be seen that four major airline hubs dominate longhaul services in Europe (BA-London Heathrow, AF-Paris CDG, KL-Amsterdam and LH-Frankfurt). These have all strengthened their position over the last three years and now have a very similar level of service with between 42 and 46 daily long haul flights by the local airline. In some cases, smaller aircraft are used than previously. BA has run-down Gatwick and moved services to Heathrow with no net growth. Air France has expanded rapidly at Paris CDG, particularly increasing the frequency of services to Latin America. KLM has likewise at Schiphol upgraded a number of sub-daily routes (mainly to Africa and Latin America) to a daily frequency. Lufthansa remains heavily focused on the North Atlantic and Asia. Zurich has conventionally been the 'number five' long-haul hub and narrowly remains so, aithough with iess than half the coverage of the big four. Swiss has nevertheiess reinstated much of the old Swissair long-haul network although continued heavy losses may not make this sustainable for very much longer. Iberia at Madrid is the other one to watch - with a doubling of daily frequencies to 16 in the last three years, it is the strongest gateway to Latin America. Of the remaining airports, Brussels has suffered badly following the demise of Sabena and Copenhagen also appears to be declining. Munich and Vienna have shown modest expansion.

Table 2 includes all long-haul points served, which offers a broader perspective. In some cases these are services by other airlines, elsewhere they are sub-daily routes by the hub major. Many secondary Asian points are served only by the foreign carrier and Caribbean points are often served by quasicharter airlines, especially in Germany, Italy and the Netherlands. It can be seen that the total longhaul network has not increased much, as airlines are tending to focus on higher frequencies to major points rather than maximising the number of places with direct service. Total network coverage has declined everywhere except London Heathrow and Munich over the last three years. Munich is still growing albeit slowly. London Heathrow has benefited from the decimation of Gatwick long-haul operations - where the total network has halved, the biggest decline of any featured airport including Brussels (where Sabena went barkrupt!). Brussels network to Africa has been maintained but with many small foreign airlines often providing low-frequency multi-stop service. Asian and North Atlantic coverage has been badly hit however. Zurich and Rome have also seen significant declines.

It is probable that the underlying reduction in demand is fairly even throughout Europe but some airlines have benefited more than others from cut-backs by the weaker players. This has enabled Air France and Lufthansa to gain market share as some of the traffic that used to pass through Gatwick, Brussels, Zurich, Copenhagen and Rome is spilled elsewhere. KLM is fighting hard to stay in the big league while BA is carrying fewer passengers in total but more via Heathrow. 
Table 1

Daily long-haul services by major hub airline in first week of July (including code-shares)

\begin{tabular}{|c|c|c|c|c|c|c|}
\hline Airport (Airline) & Year & $\begin{array}{r}\text { North } \\
\text { America }\end{array}$ & $\begin{array}{r}\text { Latin } \\
\text { America }\end{array}$ & Africa & $\begin{array}{r}\text { Asia } \\
\text { Pacific }\end{array}$ & Total \\
\hline London Heathrow (BA) & 2000 & 14 & - & 3 & 17 & 34 \\
\hline & 2003 & $\overline{18}$ & 1 & 6 & 17 & $\overline{42}$ \\
\hline \multirow[t]{2}{*}{ London Gatwick (BA) } & 2000 & 11 & 1 & 2 & - & 14 \\
\hline & 2003 & $\overline{4}$ & 1 & - & - & 5 \\
\hline \multirow[t]{2}{*}{ Paris CDG (AF) } & 2000 & $\overline{15}$ & 2 & 6 & 11 & $\overline{34}$ \\
\hline & 2003 & 15 & 8 & 9 & 14 & 46 \\
\hline \multirow[t]{2}{*}{ Amsterdam (KL) } & 2000 & 16 & 1 & 4 & 10 & 31 \\
\hline & 2003 & 18 & 6 & 7 & 14 & 45 \\
\hline \multirow[t]{2}{*}{ Frankfurt (LH) } & 2000 & $\overline{18}$ & 2 & 3 & 15 & 38 \\
\hline & 2003 & 20 & 3 & 3 & 17 & 43 \\
\hline \multirow[t]{2}{*}{ Munich (LH) } & 2000 & 5 & - & - & - & 5 \\
\hline & 2003 & $\overline{7}$ & - & - & 1 & 8 \\
\hline \multirow[t]{2}{*}{ Zurich (SR/LX) } & 2000 & $\overline{12}$ & 1 & 1 & 9 & 21 \\
\hline & 2003 & $\overline{9}$ & 1 & 1 & 7 & 18 \\
\hline \multirow{2}{*}{ Milan Malpensa (AZ) } & 2000 & $\overline{8}$ & - & 1 & 1 & 10 \\
\hline & 2003 & 7 & 1 & 1 & 2 & 11 \\
\hline \multirow[t]{2}{*}{ Rome Fiumic ino (AZ) } & 2000 & $\overline{4}$ & - & 1 & 1 & 6 \\
\hline & 2003 & 4 & - & 1 & 1 & 6 \\
\hline \multirow[t]{2}{*}{ Madrid (IB) } & 2000 & 3 & 5 & - & 1 & 8 \\
\hline & 2003 & $\overline{4}$ & 11 & - & 1 & 16 \\
\hline \multirow[t]{2}{*}{ Brussels (SN) } & 2000 & 7 & - & 1 & 1 & 9 \\
\hline & 2003 & 1 & - & 1 & - & 2 \\
\hline \multirow[t]{2}{*}{ Copenhagen (SK) } & 2000 & 4 & - & - & 4 & 8 \\
\hline & 2003 & $\overline{4}$ & - & - & 2 & 6 \\
\hline \multirow[t]{2}{*}{ Vienna (OS) } & 2000 & 2 & - & - & 1 & 3 \\
\hline & 2003 & 2 & - & - & 4 & 6 \\
\hline
\end{tabular}

Source: Compiled from OAG data

Lufthansa has launched an innovative means of providing long-haul service away from its main hub airports in Germany. This involves using a long-range Airbus A320 configured in an all business class layout. Current routes include Dusseldorf-New York and DusseldorfChicago. Such a strategy will only work where there is sufficient high yield business traffic to maintain a reasonable load factor on an everyday basis however. 
Table 2

Long-haul points served by all airlines at any frequency in first week of July

\begin{tabular}{|c|c|c|c|c|c|c|}
\hline Airport & Year & $\begin{array}{r}\text { North } \\
\text { America }\end{array}$ & $\begin{array}{r}\text { Latin } \\
\text { America }\end{array}$ & Africa & $\begin{array}{r}\text { Asia } \\
\text { Pacific }\end{array}$ & Total \\
\hline \multirow{2}{*}{ London Heathrow } & 2000 & 19 & 5 & 15 & 49 & 88 \\
\hline & 2003 & 24 & 14 & 20 & 47 & $\overline{105}$ \\
\hline \multirow[t]{2}{*}{ London Gatwick } & 2000 & 29 & 17 & 17 & 8 & 71 \\
\hline & 2003 & 19 & 9 & 5 & 3 & 36 \\
\hline \multirow[t]{2}{*}{ Paris CDG } & 2000 & 20 & 14 & 30 & 40 & 104 \\
\hline & 2003 & 18 & 15 & 27 & 43 & 103 \\
\hline \multirow[t]{2}{*}{ Amsterdam } & 2000 & 20 & 22 & 14 & 42 & 98 \\
\hline & 2003 & 24 & 20 & 14 & 37 & 95 \\
\hline \multirow[t]{2}{*}{ Frankfurt } & 2000 & 30 & 20 & 18 & 57 & 125 \\
\hline & 2003 & 33 & 18 & 20 & 51 & 122 \\
\hline \multirow[t]{2}{*}{ Munich } & 2000 & 10 & 6 & 7 & 12 & 35 \\
\hline & 2003 & 10 & 4 & 9 & 15 & 38 \\
\hline \multirow[t]{2}{*}{ Zurich } & 2000 & 13 & 4 & 19 & 27 & 63 \\
\hline & 2003 & 11 & 3 & 17 & 19 & 50 \\
\hline \multirow[t]{2}{*}{ Milan Malpensa } & 2000 & 10 & 13 & 13 & 17 & 53 \\
\hline & 2003 & 8 & 14 & 11 & 17 & 50 \\
\hline \multirow[t]{2}{*}{ Rome Fiumicino } & 2000 & 10 & 11 & 14 & 30 & 65 \\
\hline & 2003 & 8 & 6 & 11 & 29 & 54 \\
\hline \multirow[t]{2}{*}{ Madrid } & 2000 & 8 & 19 & 5 & 8 & 40 \\
\hline & 2003 & 8 & 16 & 5 & 8 & 37 \\
\hline \multirow[t]{2}{*}{ Brussels } & 2000 & 9 & - & 22 & 11 & 42 \\
\hline & 2003 & 6 & - & 20 & 5 & 31 \\
\hline \multirow[t]{2}{*}{ Copenhagen } & 2000 & 6 & 2 & 2 & 10 & 20 \\
\hline & 2003 & ó & 2 & $\overline{2}$ & 9 & 19 \\
\hline \multirow[t]{2}{*}{ Vienna } & 2000 & 4 & - & 4 & 24 & 32 \\
\hline & 2003 & 4 & - & 3 & 23 & 30 \\
\hline
\end{tabular}

Source: Compiled from OAG data

\section{Dependence upon a single airline or alliance group}

Rather than negotiating with a number of airlines on an equal basis, airports are increasingly likely to find they now have one very powerful customer. Hub airports have for some years tended to become natural monopolies as the hub airline captures almost all the transfer demand and hence will be able to support much higher frequencies than would be justified by the local traffic alone - in some cases the routes would not exist if it were not for the connection traffic. This makes it very difficult for a competitor to survive unless they are flying from a hub at the other end of the route. For example, Lufthansa accounts for $61 \%$ of scheduled flights at Frankfurt. In the US, more extreme concentrations are to be found, particularly at the medium sized hubs: USAirways has $88 \%$ of flights at Charlotte and Northwest $80 \%$ at Detroit (Airline Business, 2000). Taking a route example, Lufthansa and Alitalia operated one daily flight each between Frankfurt and Turin in 1989. By 1997 this had increased to four flights per day but they were all by Lufthansa. 
This trend has been exacerbated by airline alliance development (Morrish \& Hamilton, 2002). The key hub to hub trunk links are seeing a rapid increase in operations. For example, AmsterdamDetroit which was not served at all prior to the KLM/Northwest Alliance now has 4 flights per day by Boeing 747 or DC10; Frankfurt-Chicago has gone from 2 flights per day to 4 and CopenhagenMunich from 3 to 6 . Airports and routes which do not fit neatly into the alliance groupings are liable to see their service reduced. For example, United has pulled off Washington-Zurich to concentrate on its links with Lufthansa at Frankfurt while Delta, an Air France partner has similarly axed Washington-Frankfurt. SAS used to serve Hong Kong (now a oneworld hub) from Copenhagen but this has now lost service altogether in favour of Star Alliance connections via Bangkok using Thai, or Frankfurt using Lufthansa. Duplication is also likely to be eliminated over time (for example, Delta dropped its Frankfurt minihub to concentrate on links with partner Air France at Paris CDG instead). The ret result is that the share of traffic held by the dominant alliance at a particular airport tends to be growing rapidly while rival alliances re-deploy output elsewhere.

This poses a potential problem for airport operators. Many airports have traditiona lly been proud of the range of airlines serving their facility and will make great effort to attract another brightly coloured tailfin onto their apron. In the United States, airport expansion has often hinged around airline requirements. Airlines have also been successful in extracting generous terms from airports by playing them off against each other to be the chosen location for hub expansion. With many airports under local government control, there is a vested interest in bringing employment to the area and obtaining the greatly improved communication links, that could never be justified on the basis of local demand but can be supported on the back of the hub traffic (Small, 1997).

In Europe, airlines are trimming the large number of point to point services they historically operated from places other than their major hub. Even at the major hubs, the number of intercontinental points receiving a direct service is often diminishing as airlines re-structure around high frequency links to the key overseas hubs, with secondary cities reached through connections on partner airlines. For example, 20 years ago, SAS used to serve 36 intercontinental points from Copenhagen, many only once or twice a week with several intermediate stops; it now serves only eight but as most of these operate at least daily, more flights are actually made in total.

\section{Potential winners and losers among European cities and airports from international airline alliance formation}

Most of the global alliances contain one partner in each major region of the world, which consequently defines the key hubs. In Europe however, there is much more duplication within each alliance's coverage. The presence of many international boundaries and the historic constraints these have posed to traffic rights have created a different pattern of airline networks to the United States. Many airlines have ended up dominating a number of airports in their home country, although these are not necessarily all operated as hubs. There is thus considerable repetition in existing airline networks (e.g. British Airways can carry a passenger from Frankfurt to the US via London Heathrow, London Gatwick or Manchester), before one starts looking at the impact of alliances. US experience would suggest there are too many secondary hubs or 'focus cities' in Europe and the financial performance of these is generally poor compared to the primary hubs. The only rationale for major airlines to maintain these dispersed operations is because of capacity constraints at the 
major airports (e.g. Heathrow, Frankfurt) which prevent consolidation of operations there, or as a defensive tactic to deter a rival from invading their back-yard'. The alliance groupings have led to further overlap and the post-September 11 th downtum, together with expansion by low-cost new entrants such as Ryanair, is likely to spell the end for some of the weaker hubs.

Table 3 shows the extent to which the various combinations of European hub airports duplicate each other or serve distinct markets within each alliance group. The analysis takes only European routes which have at least $3 x$ per weekday non-stop service by the alliance partmers from the named hub. This is the minimum frequency necessary to achieve a full spread of connections. Only locations with $\mathbf{2 0}$ or more such routes are included as viable major hubs (giving 20 European hubs in total at 19 airports, Heathrow featuring in both the oneworld and Star listings). Under these criteria, the table shows the number of points that are served from each pair of hubs in the network (e.g. Frankfurt and Munich have 44 European destinations in common for the Star Alliance) and the number that are unique to that hub (e.g. the Frankfurt/Frankfurt entry shows there are 9 European points that are only served by the Star Alliance from Frankfurt). The total entry represents the total number of European destinations served from Frankfurt by the Star Alliance (65). This is not simply a total of the other entries as there are obviously some points that are served from moe than two of the listed hubs.

in the Star Alliance, the Lufthansa hubs at Frankfurt and Munich have the dominant position, as indicated in Table 3(a). There is considerable overlap between these two but Lufthansa operate them in tandem due to capacity constraints at Frankfurt. The SAS hub at Copentagen adds some additional coverage mainly in Scandinavia. Over the last decade, Copenhagen's traffic has stagnated and SAS has reduced its long-haul presence to the benefit of Lufthansa. However, SAS is now plaming to expand again in this arena. Austrian's hub at Vienna however is almost completely duplicated by Frankfurt ( 26 common routes out of 30 ). Vienna's main emphasis is in Eastern Europe-Westem Europe where it is the strongest hub with the exception of Frankfurt. Whereas Austrian would be a clear asset to any other alliance it is difficult to identify its role in Star! Stockholm Arianda is important as a niche gateway to the Sweciisi domestic market while the London Heathrow presence is comprised of 14 European trunk routes plus $8 \mathrm{UK}$ and Ireland points where bmi British Midland has the main Star Alliance presence. Heathrow is likely to be maintained as a toehold in the largest European market and an irritation to oneworld. In summary then, Vienna looks superfluous as a hub to the Star Alliance and Copenhagen is in a less than comfortable position regarding long-haul services. 
Table 3

European network coverage

Number of European airports with at least $3 \mathrm{x}$ per weekday service from each hub/pair of hubs

(a) Star Alliance

\begin{tabular}{|l|l|l|l|l|l|l|l|l|}
\hline Frankfurt & $\begin{array}{l}\text { Frankfurt } \\
9\end{array}$ & Munich & Copenhagen & Stockholm & Vienna & $\begin{array}{l}\text { London } \\
\text { LHR }\end{array}$ & Dusseldorf & TOTAL \\
\hline Munich & 44 & 4 & & & & & & \\
\hline Copenhagen & 21 & 19 & 12 & & & & & \\
\hline Stockhoim & 9 & 7 & 18 & 16 & & & & \\
\hline Vienna & 26 & 21 & 17 & 8 & 3 & & & \\
\hline $\begin{array}{l}\text { London } \\
\text { LHR }\end{array}$ & 15 & 12 & 12 & 7 & 12 & 6 & & \\
\hline Dusseldorf & 19 & 18 & 14 & 7 & 15 & 7 & 0 & \\
\hline TOTAL & 65 & 49 & 42 & 35 & 30 & 22 & 20 & 116 \\
\hline
\end{tabular}

(b) oneworld

\begin{tabular}{|l|l|ll|l|l|l|}
\hline & Madrid & $\begin{array}{l}\text { London Barcelona } \\
\text { LHR }\end{array}$ & $\begin{array}{l}\text { London } \\
\text { LGW }\end{array}$ & Helsinki & TOTAL \\
\hline Madrid & 7 & & & & & \\
\hline $\begin{array}{l}\text { London } \\
\text { LHR }\end{array}$ & 12 & 11 & & & & \\
\hline Barcelona & 29 & 12 & 3 & & & \\
\hline $\begin{array}{l}\text { London } \\
\text { LGW }\end{array}$ & 9 & 15 & 7 & 9 & & \\
\hline Helsinki & 2 & 5 & 2 & 2 & 14 & \\
\hline TOTAL & 40 & 36 & 34 & 27 & 20 & 90 \\
\hline
\end{tabular}

(c) SkyTeam

\begin{tabular}{|l|l|ll|l|l|l|}
\hline & $\begin{array}{l}\text { Paris } \\
\text { CDG }\end{array}$ & Lyon & $\begin{array}{l}\text { Milan } \\
\text { MXP }\end{array}$ & $\begin{array}{l}\text { Rome } \\
\text { FCO }\end{array}$ & $\begin{array}{l}\text { Paris } \\
\text { ORY }\end{array}$ & TOTAL \\
\hline Paris CDG & 25 & & & & & \\
\hline Lyon & 23 & 4 & & & & \\
\hline Milan MXP & 21 & 13 & 1 & & & \\
\hline Rome FCO & 17 & 10 & 20 & 4 & & \\
\hline Paris ORY & 12 & 12 & 3 & 2 & 10 & \\
\hline TOTAL & 61 & 31 & 30 & 29 & 24 & 90 \\
\hline
\end{tabular}

(d) Others with at least 20 routes at $3 x$ per day

\begin{tabular}{|l|l|l|l|l|}
\hline & $\begin{array}{l}\text { Amsterdam } \\
(\mathrm{KLM})\end{array}$ & $\begin{array}{l}\text { Zurich } \\
\text { (Swiss) }\end{array}$ & $\begin{array}{l}\text { Brussels } \\
\text { (SN) }\end{array}$ & TOTAL \\
\hline $\begin{array}{l}\text { Amsterdam } \\
\text { (KLM) }\end{array}$ & 14 & & & \\
\hline $\begin{array}{l}\text { Zurich (Swiss) } \\
\text { Brussels (SN) }\end{array}$ & 31 & 3 & 4 & \\
\hline TOTAL & 51 & 20 & 4 & 60 \\
\hline
\end{tabular}

Source: Compiled from OAG, December 2002 
Table 3(b) shows that oneworld has more limited European coverage, mainly due to the poor level of frequencies that can be operated from Heathrow and Gatwick. oneworld needs Finnair and lberia to cover the extremities of the region, which they do effectively - Iberia is now the strongest carrier in Mediterranean Europe, although the Barcelona hub is essentially a smaller version of its Madrid operation. The main scope for rationalisation must however come from British Airways' diverse presence in the UK. Gatwick is being cut back drastically (Air Transport World, 2000) and at Manchester BMI is launching a major expansion now the second nuway is open (British Midland Industry Affairs, 2000) which is likely to put further pressure on BA. Nevertheless, half the routes from Heathrow and Gatwick are still duplicated despite BA's recent reorganisation and many of these destinations are also served by BA from Birmingham or Manchester. The main stumbling block for oneworld is that Heathrow is full-up and cannot operate as an effective hub to rival Frankfurt.

In the case of SkyTeam, Air France has created in the last few years a tremendously powerful hub at CDG with still more growth potential. Alitalia does not add much to the alliance however: Table 3(c). With a split hub between Milan Malpensa and Rome as well as a residual operation at Milan Linate, despite dominating a major European market, Alitalia is not a strong partner. Malpensa, once envisaged as Alitalia's rival to Munich and Zurich now contributes little to CDG in the alliance network and Rome with its single airport and better domestic coverage may once again become the major Italian hub. Air France arguably maintains too many bases in France. Paris Oriy is likely to see its function as a domestic airport progressively eroded as the CDG hub powers ahead, although they will be anxious to keep any nvais out of the French capital. it is also uniikeiy that both Lyon and Clermont Ferrand (where Air France has acquired a small but efficient operation through the take-over of Regional Airlines) can remain as duplicated regional hubs in the longer term, only 150 km apart (Citrinot, 2000).

Two other alliances have featured in the past: KLM and Northwest's 'Wings' grouping and Qualiflyer based around Swissair. Although still one of the top three hubs, KLM has seen its strong position in Europe eroded in the last three years. It has lost alliance and code-share links with carriers such as Alitalia, Braathens and Eurowings; succumbed to low-cost competition on routes such as Stansted and Belfast and cut services such as Nice from 3x per day to $2 x$ per day. Qualiflyer has now disintegrated following the bankruptcy of Swissair but Swiss and SN Brussels still retain viable European hubs - with better coverage than Alitalia or Austrian! Swiss is coming back quite rapidly as a serious force in the long-haul arena also and could prove an attractive alliance partner. The future role of SN is less clear although Brussels is about the only 'spare' hub airport in NW Europe where there remains a general shortage of capacity. In Switzerland itself, Crossair's substantial presence at Euroairport Basle/Mulhouse and Geneva adds little to Swissair's network coverage and although some of these routes may be viable on a point-to-point basis, it is likely that much of this capacity could be more lucratively employed from an enlarged Zurich airport.

An interesting exercise is to allocate the non-aligned partners to the three major alliances and investigate where the best fit lies (Table 4). It is also possible to see how existing alliance members such as Austrian or Iberia might be better off in a different alliance. It can be seen that oneworld would be the optimal partnership in terms of European network fit for all the non-aligned airlines, principally due to the poor existing coverage of BA's Heathrow hub. KLM is least suited to Star and although there is considerable duplication with Air France's Paris CDG hub, it still adds a 
worthwhile 14 points to the SkyTeam alliance which appears to be KLM's current avenue for discussions. Swiss and SN add little value to anyone except oneworld. If all three of these airlines joined oneworld it would increase its European coverage by 20 airports to 110 points (still behind Star). If Swiss and SN only joined oneworld it would add 11 airports, still behind Star and a combined SkyTeam/KLM.

Table 4

Coverage added by non-aligned airlines when combined with major alliances

Number of European airports with at least $3 x$ per weekday service

\begin{tabular}{|l|l|l|l|}
\hline Points added to & $\begin{array}{l}\text { Amsterdam } \\
(\mathrm{KLM})\end{array}$ & Zurich (Swiss) & Brussels (SN) \\
\hline Frankfurt (Star) & 14 & 3 & 6 \\
\hline Star Alliance TOTAL & 9 & 1 & 4 \\
\hline London LHR (oneworld) & 25 & 14 & 12 \\
\hline oneworld TOTAL & 15 & 8 & 4 \\
\hline Paris CDG (SkyTeam) & 17 & 7 & 3 \\
\hline SkyTeam TOTAL & 14 & 4 & 2 \\
\hline
\end{tabular}

Source: Compiled from OAG, December 2002

Table 5 amplifies the changing position in the short-haul coverage of the major European hubs. Frankfurt and Paris CDG are forging well ahead while Amsterdam slips back. Munich and Madrid are rising in importance at the expense of Brussels and Zurich although it is noticeable that the overall picture in short-haul markets is one of growth despite the current parlous state of the aviation industry. 
Table 5

Change in European coverage of major hubs since 1999

Number of European airports with at least $3 \mathrm{x}$ per weekday service from each hub

\begin{tabular}{|c|c|c|c|}
\hline Fub & 1999 routes & 2002 routes & Change \\
\hline Frankfurt (Star) & 53 & 65 & +12 \\
\hline Paris CDG (SkyTeam) & 49 & 61 & +12 \\
\hline Amsterdam (KLM) & 69 & 51 & -18 \\
\hline Munich (Star) & $\overline{42}$ & 49 & +7 \\
\hline Copenhagen (Star) & $\overline{36}$ & 42 & +6 \\
\hline Madrid (oneworid) & 29 & 40 & +11 \\
\hline London LHR (oneworld) & 31 & 36 & +5 \\
\hline Zurich (Swiss) & 41 & 36 & -5 \\
\hline Stockholm (Star) & 36 & 35 & -1 \\
\hline Barceiona (oneworid) & 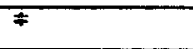 & 34 & $\hat{\mathbf{N A}}$ \\
\hline Brussels (SN) & 50 & 31 & -19 \\
\hline Lyon (SkyTeam) & 20 & 31 & +11 \\
\hline Milan MXP (SkyTeam) & 30 & 30 & 0 \\
\hline Vienna (Star) & 28 & 30 & +2 \\
\hline Rome FCO (SkyTeam) & 26 & 29 & +3 \\
\hline London LGW (oneworid) & 28 & 27 & -1 \\
\hline Paris ORY (SkyTeam) & 24 & 24 & 0 \\
\hline London LHR (Star) & 20 & 22 & +2 \\
\hline Dusseldorf (Star) & * & 20 & NA \\
\hline Helsinki (Star) & 21 & 20 & -1 \\
\hline EuroAirport (Swiss) & 21 & * & $\overline{\text { NA }}$ \\
\hline
\end{tabular}

* less than 20 routes operated $3 x$ per weekday

Source: Compiled from OAG data

\section{Future of the global alliances and implications for European hubs}

The future development of the global airline alliances has potentially significant implications for the role of different hub aipports in Europe and around the world. To date, the alliance groupings have been in a continual state of flux and we are unlikely to have reached the final form yet (Agusdinata \& de Klein, 2002). The level of integration within many of the alliances is far from perfect however and it is quite possible that airlines within the same alliance will continue to compete in the way they have always done, paying little regard to the strategies of their supposed partners!

Within the current alliances, the odds of United surviving now look considerably better than six months ago. The Star Alliance is also about to gain US Airways which has restructured fairly successfully (Travel Trade Gazette, 2003). This is likely to strengthen the hand of Lufthansa in Europe as more North Atlantic capacity is flown to Star hubs. However, the future of Virgin Atlantic is one of the big unknowns. Despite being $49 \%$ owned by Star member Singapore Airlines, Virgin has remained resolutely outside the major groupings, instead favouring a block space agreement with Continental. Current interest focuses on the scope for a bmi-Virgin merger which would give Star a serious presence at London Heathrow and create a 6rmidable rival to BA (Noakes, 2003). SAS has recently questioned whether it should be continuing in the long-haul 
market and may be the first of the smaller European flag carriers to reduce to a purely short-haul network, feeding other alliance partners with longer distance traffic (Campbell, 2003).

KLM and Northwest have to decide whether they will expand to create the much vaunted 'Wings' alliance and find some suitable Asian and Latin American partners (there are carriers in these regions that may not be entirely happy in their existing alliances). This would be a perfectly viable grouping, competitive with the other three and would maximise consumer choice and the number of parallel hubs that can be maintained.

It now seems more likely however that SkyTeam will absorb KLM-Northwest, along with Continental. As Delta, Northwest and Continental have created a three-way alliance in the US, the international partnerships are likely to combine also. This is a serious risk for KLM as Air France's major hub at CDG is too near and too similar for both to prosper. Paris is always likely to be the bigger and more attractive market to serve in Europe than Amsterdam and one can envisage Northwest and Continental refocusing there. Alitalia is struggling to find a role in longhaul services and this also should strengthen the hand of Air France. The other possible destination for Virgin Atlantic would be SkyTeam, if bmi becomes a rival North Atlantic operator at Heathrow. However, it is fairly inconceivable that SkyTeam would wish to use London as a hub.

Another possible switch of alliances involves KLM abandoning Northwest and moving to oneworld. The fit between KLM and BA is relatively good in Europe and with Heathrow capacity constrained and the Gatwick strategy failed, BA might well prefer to promote Amsterdam as a third major hub to Paris and Frankfurt. This would appear to offer the best future for Amsterdam and for maintaining all the major European hubs in the longer term under an outcome of three global alliances. It is not inconceivable that KLM and Northwest could both move to oneworld as Northwest has reasonable synergy with American on long-haul routes, if not an ideal fit domestically. If BA misses out on KLM than Swiss is likely to be its preferred option for filling oneworld's gap in mainland Europe. However, although Swiss badly needs a partnership, it is doubtful that anyone will wish to take them on while their finances are still far in the red.

It is difficult to see an obvious route to two global alliances from the current position. This would seem to require the failure or merger of one of the six US international carriers. A combined DeltaContinental-United (with Air France and Lufthansa in Europe) might balance against AmericanNorthwest-US Airways (with BA and KLM in Europe) but requires splitting the existing partnerships.

A more likely scenario where mergers start to occur between major airlines is that some airlines will then find themselves in two alliances and to overcome competition concerns or local monopolies in certain parts of the world (e.g. Australasia where Qantas is likely to dominate), the fair and easy solution is to merge the alliances so that we return to one industry alliance (IATA by any other name) where all the carriers co-operate with each other. This avoids smaller airlines being disadvantaged and would favour the smaller hubs and the less coordinated or multi-airline hubs such as London over the one-airline dominant hubs such as Frankfurt. 


\section{Airline service at second-tier cities}

It is probable that less air service will be provided at the medium sized cities by the traditional national flag carriers in the future. These do not offer the network synergies of the main hubs and are exposed to competition from low-cost airlines when traffic is mainly 'point to point'. Where there is room for conventional service, it is increasingly likely to be provided by foreign airlines, for whom it is a 'spoke' point or specialist regional operators using small aircraft.

Table 6 analyses the change in scheduled services at Birmingham and Belfast Intemational over the last three years. It can be seen that BA has reduced frequencies at Birmingham (and down-sized aircraft, so capacity reduction is even greater), as have most of the other traditional carriers. The low-cost sector has grown from 4 flights per day to 26. At Belfast Intemational, the eclipse of the traditional airlines is almost total. Whereas BA and British Midland still dominated services here as recently as three years ago, they have moved what is left of their Northem Ireland operation to Belfast City, surrendering Belfast International to easyJet.

The low-cost airlines will maintain a reasonable level of direct air service from such cities at competitive fares. They may not be profitable to the airport operator however due to their unwillingness to pay normal airport charges. The other shortcoming is that they do not provide the giobai accessibility of a conventional hub link, as flights cannot be booked through the GDS, there is no through pricing or schedule co-ordination. This makes low-cost services almost unusable for connecting journeys.

Table 6

Service at Birmingham and Belfast International July 2000 and July 2003

\begin{tabular}{|c|c|c|c|c|}
\hline Airline & $\begin{array}{r}\text { Birmingham } \\
2000 \\
\end{array}$ & $\begin{array}{r}\text { Birmingham } \\
2003 \\
\end{array}$ & $\begin{array}{r}\text { Belfast Intl } \\
2000 \\
\end{array}$ & $\begin{array}{r}\text { Belfast Intl } \\
2003\end{array}$ \\
\hline Pritish A irways* & 83 & 70 & 22 & \\
\hline British Midland* & 14 & 10 & 12 & \\
\hline British Furonean & 26 & 27 & & \\
\hline Other Traditional & 29 & 28 & 1 & $\overline{1}$ \\
\hline Total Traditional & 152 & 135 & 35 & $\overline{1}$ \\
\hline easyJet & & & 7 & 33 \\
\hline Ryanair & 4 & 3 & & \\
\hline My Travel Lite & & 16 & & 2 \\
\hline bmibaby & & & & 6 \\
\hline Fresh Aer & & 7 & & \\
\hline Total Low-cost & 4 & 26 & 7 & 41 \\
\hline Overall Total & 156 & 161 & 42 & 42 \\
\hline
\end{tabular}

* including franchises and code-shares

Source: Compiled from OAG data

The traditional airlines have favoured airports which have kept the low-cost carriers out - this usually requires either a restricted runway or high user charges. For example, British Airways have launched services this Spring from London City and it remains the only London airport other than Heathrow to be served by most of the European national carriers. London City's runway is to o short 
to handle 737 jets. Other examples include Southampton, chosen for expansion by British European (Flybe) who have been chased out of many of their traditional markets and Manchester, where there is only a minimal low-cost presence, receiving new BA services.

\section{Conclusion}

The difficult business conditions of the last two years have led to some retrenchment of long-haul services from European airports. Certain low frequency destinations have been discarded in favour of higher frequencies on the trunk routes. The four largest airlines have widened the gap with the rest by continuing to expand intercontinental services at their major hub airports. The greatest cutbacks have been by British Airways at London Gatwick - as part of the airline's 'future size and shape' review and Brussels where only part of Sabena's long-haul service has been replaced by other carriers. Overall however, most of the smaller national carriers continue to stubbornly hang-on in the long-haul market even though many of them are losing large amounts of money in doing so. Swiss has recreated much of the former Swissair network although it has little unique coverage compared to the larger airlines. Iberia is perhaps the only carrier outside the big four that has a clear and defendable niche in long-haul operations with its extensive Latin American network.

Within Europe, most of the hubs have actually expanded in the last three years. One of the few losers is KLM at Amsterdam, which has become isolated from many of its former feeder partners such as Eurowings, Braathens and Alitalia. SN at Brussels is also a pale shadow of the former Sabena operation. Even airlines which have decided to reduce their long-haul presence have maintained their short-haul networks, such as BA at Gatwick and SAS at Copenhagen.

The low-cost airlines currently have only about $15 \%$ of the intra-European market but this is rising rapidly. In the UK and Ireland they are now over $30 \%$ of short-haul scheduled traffic - higher than in the US domestic market where Southwest has been operating for 30 years! It seems likely that the natural market share of low-cost airlines operating 'point to point' services, often from secondary airports may be around a third. Although some of this traffic is new growth, it means that the traditional airlines are going to have to review their short-haul strategies and withdraw from markets where they do not have a strong competitive position and do not require long-haul feed. The example of Belfast International shows how a medium sized market can be dominated by the lowcost carriers and other places where the majors are likely to be squeezed include Birmingham, London Gatwick, Brussels, Geneva, Paris Orly, Milan and Nice.

Hubs are not going to go away however. Indeed, for the majors they remain crucial to maintain some competitive advantage over the low-cost new entrants and to feed the long-haul flights for which demand is much more dispersed. The main strategic response of the major airlines to changing industry conditions has been to group themselves into international alliances. This only brings efficiencies however if accompanied by some rationalisation and identification of complementary roles. Europe continues to have too many airlines attempting to operate hubs in close proximity to each other and certain locations such as Vienna, Milan Malpensa and Barcelona add little to their relevant alliance and appear to be prime candidates for hub withdrawal.

For the cities which find their airport marginalised in terms of alliance strategy or de-hubbed as a result of airline industry consolidation, the economic consequences are potentially severe. As well 
as losing direct employment there is a penalty in terms of accessibility to the rest of Europe and the world. Brussels, for examp le, saw its level of air service collapse on the demise of Sabena. This then makes the city less attractive as a location for business, leading potentially to a spiral of decline. In the US, Boeing recently moved its corporate headquarters from Seattle to Chicago, citing the much better level of non-stop air service available there. Whereas once geographical patterns of demand determined the configuration of airline networks, now it is the network strategies of airlines that can have a profound effect on geographical patterns of industrial location and economic activity.

Although the current downturn has produced relatively few changes in the European airline industry, several significant developments lie around the corner. The EU is about to start negotiating air services agreements with outside countries to replace the old bilaterals and there are strong signs that national ownership rules will disintegrate. The biggest restructuring may still be yet to come.

\section{References}

Agusdinata, B. \& de Klein, W. (2002). The dynamics of airline alliances. Journal of Air Transport Management, 8(4), pp. 201-211.

Airline Business (2000). Airports special report. June, pp. 55-66.

Air Transport World (2000). BA begins network restructuring. November, p. 9.

British Midland Industry Affairs (2000). Our vision for Manchester: The development of Manchester airport as a new hub. London: British Midland Airways.

Campbell, A. (2003). SAS questions its long-haul furure. Flight International, 27 May-2 June, p. 26.

Citrinst. Y. (2000). Growth masks comnetition: Airline alliances pose a threat to French provincial airports. Jane's Airport Review, June, p. 13.

Denton, N. \& Dennis, N. (2000). Airline franchising in Europe: Benefits and disbenefits to airlines and consumers. Journal of Air Transport Management, 6(4), pp. 179-190.

Halstead, J. (2001). Has downsizing worked? Aviation Strategy, April, pp. 6-9.

Hanlon, P. (1999). Global Airlines (2nd ed.). Oxford: Butterworth-Heinemann.

Morrish, S.C. \& Hamilton, R.T. (2002). Airline alliances - who benefits? Journal of Air Transport Management, 8(6), pp. 401-407.

Noakes, G. (2003). BMI/Virgin deal 'unlikely'. Travel Trade Gazette, 2 June, p. 4.

Small, N.O. (1997). Making the right connection: Airline deregulation, airline service and metropolitan economic development. Unpublished doctoral dissertation, University of Reading.

Travel Trade Gazette (2003). Star Alliance welcomes US Airways. 9 June, p. 21. 